\title{
PENGEMBANGAN SUMBER DAYA EKONOMI LOKAL DI KABUPATEN SUMENEP: PENDORONG DAN PENGHAMBAT
}

\author{
Mochammad Rozikin", Rillia Aisyah Haris ${ }^{*}$ \\ 1)Fakultas Ilmu Administrasi Universitas Brawijaya \\ 2)Fakultas Ilmu Sosial dan Ilmu Politik Universitas Wiraraja \\ *)Korespondensi: rillia@wiraraja.ac.id
}

Article Histori:

Accepted: $12 / 8 / 2021$

Review: 20/9/2021

Publish: 31/10/2021

\section{Abstract}

The purpose of this study is to identify and analyze the drivers and restraining factors of the development of local economic resources. This study uses force field analysis to analyze the various forces / factors that affect a change, determine the source of its strength, and develop strategies to strengthen the drivers and weaken the inhibitors. The results showed that there were a number of driving factors, namely: 1) superior commodities; 2) Rules ( policies; 3) Budget allocation; 4) Human resources availability; 5) Leadership. The restraining factors are: 1) Lack of coordination and collaboration of stakeholders involved; 2) The quality of human resources of farmers is still low; 3) community participation is still low; 4) Availability of infrastructure; 5) Commitment of stakeholders involved. This research is expected to be a material consideration for developing strategies to achieve success in developing local economic resources and providing recommendations to local governments to implement planned changes to be able to increase the added value and welfare of local communities.

Keyword: local economic development; driving force; restraining force

\section{PENDAHULUAN}

Pembangunan ekonomi lokal merupakan usaha penguatan daya saing ekonomi lokal guna pengembangan ekonomi daerah, yang dalam prosesnya pemerintah lokal dan organisasi berbasis masyarakat harus terlibat dalam mendorong, merangsang atau memelihara aktivitas masyarakat atas penciptaan lapangan kerja, sebagai solusi dalam pemulihan dan pengembangan perekomian nasional, terutama dalam pendayagunaan potensi ekonomi dimasingmasing daerah dengan berbasis pada sumber daya yang dimiliki oleh masyarakatnya masing-masing (Wiranta, 2015).Berdasarkan pengalaman pelaksanaan pembangunan yang banyak dilakukan selama ini baik di tingkat nasional maupun daerah telah terbukti bahwa pemecahan terhadap persoalan-persoalan ekonomi selama ini dilakukan secara parsial, entah itu sektoral atau kedaerahan, sehingga tidak mampu secara efektif mencapai tujuan pembangunan ekonomi yang maksimal. Bahkan bukan tidak mungkin cara tersebut dapat menimbulkan persoalan baru dan memperburuk persoalan-persoalan di sisi yang lain. Sesuai dengan sasaran jangka panjang dan tujuannya, pendekatan PEL menekankan pada tercapainya pertumbuhan ekonomi melalui penciptaan nilai tambah, penciptaan kesempatan kerja baru, pemerataan pendapatan diantara masyarakat terutama masyarakat miskin dan meningkatkan daya saing daerah. Hal tersebut pada akhirnya bermuara pada sasaran utama jangka panjang yaitu pengurangan kemiskinan secara signifikan 
dan peningkatan kesejahteraan kehidupan masyarakat lokal.

Pendekatan PEL merupakan pendekatan yang holistik dan komprehensif serta menekankan pada keterkaitan dan sinergi antar sektor dan seluruh strategi pembangunan yang ada dalam suatu wilayah tertentu. PEL bertumpu pada tiga komponen yang disebutkan sebelumnya, bahwa pendekatan PEL diharapkan mampu menyediakan ruang dan membuka kesempatan bagi pemerintah daerah, dunia usaha dan masyarakat untuk memperbaiki interaksi diantara mereka serta menawarkan berbagai pilihan strategi yang dapat digunakan untuk mendorong pembangunan ekonomi daerah melalui pemanfaatan sumber daya dan keterampilan yang dimiliki. Melalui suatu wadah kerja sama (kemitraan) multi stakeholder yang dibangun dan berfungsi sebagai media partisipasi masyarakat dan forum dialog antar stakeholder misalnya, pendekatan PEL diharapkan dapat membawa pada kondisi di mana perencanaan, perumusan dan pengambilan keputusan mengenai kegiatan pembangunan (termasuk pengalokasian APBD) dibuat berdasarkan kebutuhan yang ada dan benar-benar ditujukan untuk memecahkan permasalahan yang dihadapi masyarakat. Pendekatan PEL juga diharapkan dapat menghasilkan perbaikan kebijakan yang mampu mendukung terciptanya iklim yang kondusif dan menguntungkan, baik bagi masuknya investasi baru maupun mendukung pertumbuhan dan perkembangan usaha yang telah ada.

Kabupaten Sumenep sebagai salah satu kabupaten di ujung timur pulau Madura Propinsi Jawa Timur memiliki misi salah satunya yaitu "Meningkatkan kemandirian perekonomian pedesaan dan perkotaan dengan memperhatikan potensi ekonomi lokal yang unggul berdaya saing tinggi". Salah satu upaya yang dilakukan yaitu dengan melaksanakan program pengembangan kawasan agropolitan, dengan komoditas bawang merah sebagai komoditas unggulan yang sedang dikembangkan.

Berdasarkan informasi di situs resmi Kementerian Pertanian bidang litbang Tahun 2019 bahwa bawang merah Sumenep merupakan komoditas yang sangat potensial untuk dikembangkan. Bawang merah Sumenep merupakan varietas lokal "rubaru" yang berasal dari seleksi kultivar lokal Sumenep Madura terbukti tahan di segala cuaca dan dapat bertahan terhadap penyakit fusarium dan alternaria, serta serangan hama ulat grapyak (spodoptera exigua). Selain itu juga rubaru dapat beradaptasi dengan baik di dataran rendah sampai medium baik pada musim hujan maupun musim kemarau, dengan potensi hasil umbi kering sekitar 14-17 ton per hektar. Hal tersebut menyebabkan petani tetap dapat meraup keuntungan sekalipun pada musim hujan atau off season. Hal ini yang kemudian menjadi keunggulan dan membedakan dengan daerah penghasil bawang merah lain di Indonesia seperti Brebes, Batu atau Probolinggo. Kecamatan Rubaru saat ini menjadi pusat produksi bawang merah di Kabupaten Sumenep, dengan luas areal tanam mencapai 1.300 hektar, dan produktivitas sebesar delapan ton per hektar. Petani setempat bisa menanam bawang merah sebanyak tiga kali dalam setahun, yaitu pada bulan FebruariMaret, Mei-Juni, dan Oktober-November. Nilai tambah lain dari varietas Rubaru adalah produk olahan yaitu memiliki kekhasan lebih crispi, aroma lebih harum, serta lebih enak untuk bawang goreng. Namun potensi menjanjikan untuk dikembangkan tersebut menyimpan berbagai permasalahan meliputi ketersediaan sarana dan prasarana produksi yang masih minim dan tradisional, akses dan fasilitas jalan yang masih belum memadai, pemenuhan kebutuhan benih 
yang masih minim karena saat ini hanya memiliki dua orang penangkar saja, permodalan, jaringan pemasaran, minimnya pengetahuan dan keterampilan dalam pengolahan bawang merah menjadi produk olahan yang memiliki nilai ekonomis yang lebih tinggi. Permasalahan tersebut tentunya perlu segera diatasi agar mampu mewujudkan peningkatan kesejahteraan petani dan peningkatan perekonomian daerah berbasis potensi sumber daya lokal. Namun demikian, upaya pengembangan ekonomi lokal bukanlah proses yang mudah dan singkat. Terdapat banyak faktor yang mendukung sekaligus juga menghambat keberhasilan dari pengembangan ekonomi lokal. Terdapat sejumlah faktor pendukung dan kendala dalam pengembangan ekonomi lokal yaitu kapabilitas kolaborasi, regulasi, kepemimpinan, sistem kolaborasi, perencanaan kolaboratif, legitimasi, konsensus tujuan bersama. Faktor faktor tersebut memicu bagi munculnya faktor lainnya yaitu partisipasi masyarakat, komitmen, konflik kepentingan, kepercayaan, komunikasi, motivasi dan keadilan (Najiyati, S; Simanjuntak, RA; Nurwati, 2015)

Dengan memperhatikan beberapa permasalahan tersebut diatas, maka perlu dilakukan penelitian lebih lanjut untuk mengidentifikasi faktor pendorong dan penghambat dalam pengembangan sumber daya ekonomi lokal. Hal ini dilakukan dengan harapan agar mampu menyusun strategi yang tepat untuk mencapai tujuan pengembangan ekonomi lokal yaitu meningkatkan kesejahteraan sosial bagi masyarakat lokal.

\section{KAJIAN LITERATUR}

Penelitian ini terinspirasi dari beberapa penelitian terdahulu yang memiliki tema yang sama yaitu pengembangan potensi ekonomi lokal, diantaranya oleh (Blakely, 1994) bahwa pembangunan ekonomi lokal merupakan suatu upaya pemerintah lokal dan organisasi masyarakat terlibat untuk mendorong, merangsang, memelihara aktivitas usaha untuk menciptakan lapangan pekerjaan. Adapun kriteria ekonomi lokal yaitu: 1) Bahan baku dan sumber daya lokal; 2) Dapat digerakan oleh penduduk lokal/ sesuai dengan kemampuan penduduk (SDM) lokal; 3) Pengusaha dan tenaga kerja dominan adalah tenaga kerja lokal; 4) Melibatkan sebagian besar penduduk lokal; 5) Skala pelayanan kecil ditunjukkan oleh jumlah investasi dan jumlah tenaga kerja; 6) Terdapat organisasi/ kelompok kegiatan ekonomi; 7) Terdapat keterkaitan dengan kegiatan ekonomi lain; 8) Memunculkan wiraswasta baru.

Penelitian ini juga didukung oleh (Swinburn, Gwen; Goga, Soraya; Murphy, 2006) bahwa pembangunan ekonomi lokal merujuk pada upaya peningkatan standart hidup masyarakat lokal dengan pertumbuhan ekonomi yang berkelanjutan. Pembangunan ekonomi lokal mencakup proses dan kebijakan yang dilaksanakan untuk memperbaiki perekonomian dan kesejahteraan masyarakat lokal. Menurut (Swinburn, Gwen; Goga, Soraya; Murphy, 2006) tujuan dari pengembangan ekonomi lokal adalah untuk membangun kapasitas ekonomi untuk meningkatkan perekonomian lokal di masa depan dan meningkatkan kualitas hidup masyarakat. Pengembangan ekonomi lokal merupakan sebuah proses yang melibatkan sektor publik, bisnis dan sektor non pemerintah yang berkolaborasi untuk menciptakan pertumbuhan ekonomi dan membuka kesempatan kerja. Konsep pengembangan ekonomi lokal berfokus pada kekuatan untuk memobilisasi sumber daya, kapasitas dan keterampilan yang dimiliki pemerintah daerah untuk dimanfaatkan bagi tercapainya tujuan pembangunan ekonomi daerah.

Sementara itu menurut (Rahma, 2012) pengembangan ekonomi lokal dapat dimaknai sebagai hubungan kerja sama kolektif antara pemerintah, dunia usaha 
serta sektor non pemerintah dan masyarakat untuk mengidentilikasi dan memanfaatkan secara optimal sumber daya yang dimiliki dalam upaya merangsang dan menciptakan perekonomian lokal yang kuat, mandiri dan berkelanjutan. Berdasarkan definisi tersebut terdapat dua kata kunci yang dapat diambil yaitu: 1) kerja sama antar semua komponen dan 2) pemanfaatan sumber daya lokal secara optimal. Kedua kata kunci tersebut sekaligus merupakan komponen pendekatan pengembangan ekonomi lokal dan tentunya keduanya sangat relevan dengan semangat desentralisasi di mana pemerintah daerah bersama-sama dengan seluruh komponen di dalamnya dan dituntut untuk mampu mengelola daerahnya sendiri dan mampu mengubah potensi lokal yang dimiliki menjadi kekuatan ekonomi sebagai sumber pertumbuhan dan perbaikan kualitas hidup penduduknya. Pendapat ini dikuatkan oleh pernyataan (Pike et al., 2015) bahwa dalam mewujudkan keberhasilan pengembangan ekonomi lokal maka perlu pemahaman tentang konteks geografis yang berbeda, keberadaan, tingkat, arah dan karakter hubungan antara institusi yang terlibat, selain itu juga dibutuhkan pemahaman tentang berbagai peran dan fungsi lembaga dalam pembangunan ekonomi di tingkat lokal.

Terdapat sejumlah prinsip utama yang mendasari konsep pengembangan ekonomi lokal di antaranya adalah sebagai berikut: 1) Kemiskinan dan pengangguran merupakan tantangan utama yang dihadapi daerah sehingga strategi PEL harus memprlorltaskan pada peningkatan kesempatan kerja dan pengentasan kemiskinan; 2) PEL harus menetapkan target pada masyarakat kurang beruntung. pada area dan masyarakat yang cenderung termarjinalkan pada usaha mikro dan kecil sehingga memungkinkan mereka untuk berpartisipasi nyata dalam kehidupan ekonomi setempat; 3) Setiap daerah perlu mengembangkan dan memiliki sendiri strategi PEL yang sesuai dengan kondisi daerahnya; 4) PEL mendukung kepemilikan lokal, keterlibatan masyarakat, kepemimpinan lokal dan pengambilan keputusan bersama; 5) PEL menuntut terbangunnya kemitraan antara masyarakat, sektor usaha dan swasta serta pemerintah daerah untuk memecahkan masalah bersama; 6) PEL memaksimalkan pemanfaatan sumber daya lokal. kemampuan. ketrampilan dan peluang bagi pencapaian berbagai tujuan;7) PEL memberikan keleluasaan bagi daerah untuk merespon perubahan lingkungan yang terjadi baik di tingkat lokal, nasional maupun internasional (Rahma, 2012).

Fokus Pembangunan Ekonomi Lokal meliputi: 1)Peningkatan kandungan lokal; 2) Pelibatan stakeholders secara substansial dalam suatu kemitraan strategis; 3) Peningkatan ketahanan kemandirian ekonomi; 4) Pembangunan berkelanjutan; 5) Pemanfaatan hasil pembangunan oleh sebagian besar masyarakat lokal; 6) Pengembangan usaha kecil dan menengah; 7) Pertumbuhan ekonomi yang dicapai secara inklusif; 8) Penguatan kapasitas dan peningkatan kualitas SDM; 9) Pengurangan kesenjangan antar golongan masyarakat, antar sektor dan antar daerah; 10) Pengurangan dampak negatif kegiatan ekonomi terhadap lingkungan.

Adapun sasaran jangka panjang dari penerapan pendekatan PEL adalah pengentasan kemiskinan dan perbaikan yang terus menerus dan berkelanjutan dalam kualitas kehidupan dari suatu komunitas lokal di suatu daerah/wilayah. Dalam rangka mencapai sasaran tersebut pengembangan ekonomi lokal memiliki tujuan yaitu: 1) Mempercepat pertumbuhan ekonomi melalui penciptaan nilai tambah; 2) Menciptakan dan memeratakan kesempatan kerja; 3) Meningkatkan pendapatan dan memperbaiki distribusi pendapatan masyarakat; 4) Meningkatkan daya saing 
ekonomi daerah terhadap daerah atau negara lain; 5) Membangun dan mengembangkan kerja sama yang positif antar daerah (Rahma, 2012).

Rofikoh Rokhim et al (2016) dengan penelitiannya yang berjudul "Analyzing Key Success Factors Of Local Economic Development In Several Remote Areas In Indonesia". Tujuan dari penelitian ini adalah untuk menganalisis potensi daerah-daerah terpencil di Indonesia dan mencari tahu variabel-variabel penting yang mempengaruhi faktor-faktor kunci keberhasilan Pengembangan Regional Ekonomi Daerah (LERD) di beberapa daerah terpilih di Indonesia (Bau Bau, Singkawang, Kupang). Penelitian LERD didasarkan pada inisiatif lokal, didorong oleh pemangku kepentingan lokal, dan melibatkan identifikasi dan penggunaan sumber daya terutama yang tersedia secara lokal, ide dan keterampilan secara terpadu untuk merangsang pertumbuhan ekonomi dan pembangunan. Penelitian ini menggarisbawahi bahwa pengembangan regional ekonomi lokal untuk peningkatan kualitas kehidupan lokal sangat bergantung pada kualitas masyarakat setempat, karakteristik sumber daya produksi, partisipasi stakeholder, kegiatan kewirausahaan dan pemberdayaan lokal.

Canzanelli (2001) sebagaimana dikutip Rokhim (2016: 452) menunjukkan bahwa pembangunan ekonomi di tingkat lokal adalah proses di mana pemangku kepentingan lokal bekerja secara kohesif. Proses seperti itu akan merangsang dan memfasilitasi kemitraan antara pemangku kepentingan lokal, memungkinkan desain bersama dan implementasi strategi. Hasil penelitian menunjukkan beberapa variabel yang menjadi faktor kunci dalam pengembangan ekonomi lokal di Indonesia yaitu institutions, natural resources, infrastructure technology, local government, social capital dan financial capital. Semua variabel tersebut digunakan sebagai indikator atau parameter dalam melakukan FGD, metode survei dan wawancara mendalam. Meskipun variabel kunci masih berkembang selama proses penelitian ini, setidaknya ada tiga variabel penting yang harus diukur: kegiatan kewirausahaan, pemberdayaan dan pemimpin lokal.

Adapun mengenai posisi penelitian ini merupakan penelitian yang sifatnya meneruskan ataupun melengkapi keanekaragaman penelitian dengan tema yang sama mengenai pengembangan ekonomi lokal. Nilai kebaruan dari penelitian ini terletak pada perspektif yang digunakan yaitu Local Economic Resources Development yang dipotret dari salah satu potensi sumber daya lokal Kabupaten Sumenep yaitu bawang merah. Fokus penelitian yang digunakan dalam menganalisa dan menginterpretasi pengembangan potensi ekonomi lokal berbasis local economic resources development diidentifikasi dari berbagai sumber yang kemudian disesuaikan dengan kondisi lokal Kabupaten Sumenep agar nantinya dapat digunakan sebagai pisau analisis yang membumi.

\section{METODE PENELITIAN}

Penelitian ini menggunakan force field analysis untuk menganalisis berbagai kekuatan atau faktor yang mempengaruhi suatu perubahan (misalnya: implementasi kebijakan), mengetahui sumber kekuatannya, dan memahami apa yang bisa kita lakukan terhadap faktor-faktor kekuatan tersebut, dalam hal ini adalah faktor pendukung dan faktor penghambat dari pengembangan sumber daya ekonomi lokal di Kabupaten Sumenep. Force field analysis merupakan metode yang dikembangkan oleh Kurt Lewin. Analisis kekuatan medan mengusulkan bahwa perubahan dapat terjadi apabila kekuatan pendorong untuk perubahan lebih besar daripada faktor 
penahan yang melawan perubahan (Daft, $R$. L., \& Marcic, 2016).

Penelitian ini menggunakan force field analysis secara kualitatif dengan teknik wawancara semi terstruktur, pengalaman peneliti, brainstorming yang dipandang akan lebih mengeksplorasi dan memperkaya analisis penelitian (Swanson \& Creed, 2014). Beberapa tahapan perlu dilakukan dalam force field analysis. Menurut (Cordell et al., 2019) terdapat beberapa tahapan yang harus dilakukan dalam analisis kekuatan medan antara lain mengidentifikasi faktor pendorong dan penghambat perubahan, menilai potensi kekuatan dengan menentukan skor pada kekuatan pendorong maupun penghambat, menciptakan keseimbangan untuk mewujudkan perubahan yang diharapkan dengan menambahkan kekuatan pendorong dan mengurangi kekuatan penghambat, melakukan monitoring terhadap dampak dan manfaat yang dihasilkan dari perubahan.

\section{HASIL DAN PEMBAHASAN}

Upaya pengembangan sumber daya ekonomi lokal telah dilaksanakan di Kabupaten Sumenep melalui program pengembangan kawasan agropolitan sejak tahun 2011 dengan komoditi bawang merah sebagai komoditi unggulan daerah. Upaya pengembangan sumber daya ekonomi lokal ini dianalisis menggunakan force field analysis. Force field analysis digunakan untuk mengidentifikasi faktor pendukung dan faktor penghambat perubahan terencana yang ditujukan untuk memecahkan masalah dalam suatu organisasi. FFA (force field analysis) dilakukan dengan metode kualitatif, penetapan skor didasarkan pada keyakinan peneliti terhadap temuan penelitian tentang faktor-faktor yang mempengaruhi upaya pengembangan sumber daya ekonomi lokal di Kabupaten Sumenep.

Berdasarkan hasil penelitian, telah diidentifikasi dan dianalisa faktor-faktor pendorong dan faktor-faktor penghambat dalam pengembangan sumber daya ekonomi lokal di Kabupaten Sumenep. Faktor pendorong tersebut meliputi:

\section{Adanya aturan dan kebijakan pemerintah yang mendukung.}

Dalam upaya pengembangan potensi ekonomi lokal, otonomi daerah merupakan momentum yang tepat bagi seluruh pemerintah daerah di Indonesia untuk bangkit bergerak melaksanakan pembangunan daerah dengan memaksimalkan potensi ekonomi lokal yang dimilikinya untuk mewujudkan kesejahteraan masyakarat. Otonomi daerah di Indonesia mulai bergulir sejak dikeluarkannya Undang-Undang No. 22 Tahun 1999 yang diperbaharui dengan dikeluarkannya UndangUndang No. 32 Tahun 2004 tentang Pemerintah daerah yang isinya lebih kepada desentralisasi politik. Sedangkan desentralisasi fiskal diatur dalam Undang-Undang No. 25 Tahun 1999 yang kemudian diperbaharui dengan dikeluarkannya Undang-Undang No. 33 Tahun 2004 tentang Hubungan Keuangan Antara Pemerintah Pusat dan Pemerintahan Daerah. Dengan diberlakukannya undang-undang tersebut pemerintah daerah memasuki era baru yaitu era otonomi daerah dan desentralisasi. Pemerintah daerah diberi kewenangan dalam mengatur rumahtangganya sendiri, mendorong proses pembangunan di daerahnya masing-masing dan selanjutnya turut serta mendorong proses pembangunan nasional secara keseluruhan. Diberlakukannya desentralisasi dan otonomi daerah dikarenakan pemerintah memiliki keterbatasan dalam hal kapasitas dan sumber daya untuk melakukan pembangunan ekonomi setiap daerah secara terpusat. Sebagaimana termaktub dalam pasal 14 ayat 2 Undang-Undang No. 32 Tahun 2004 bahwa "urusan pemerintahan kabupaten/ kota yang bersifat pilihan meliputi urusan pemerintahan yang secara nyata ada dan 
berpotensi untuk meningkatkan kesejahteraan masyarakat sesuai dengan kondisi, kekhasan dan potensi unggulan daerah yang bersangkutan". Untuk itulah diperlukan strategi dan upaya pemanfaatan sumberdaya menggerakkan ekonomi lokal dengan meningkatkan peran swasta (dunia usaha), masyarakat, perguruan tinggi, perbankan dan media massa melalui kerangka regulasi, kerangka investasi, dan layanan publik. Upaya pengembangan sumber daya ekonomi lokal di Kabupaten Sumenep ditindaklanjuti dengan dilaksanakannya program pengembangan kawasan agropolitan untuk memaksimalkan potensi pertanian yang dimiliki oleh Kabupaten Sumenep. Program tersebut dapat dicapai dengan pengembangan sistem dan usaha agribisnis yang berdaya saing dan berbasis kerakyatan. Kabupaten Sumenep juga ditetapkan sebagai salah satu lokasi pengembangan kawasan agropolitan di Jawa Timur ditandai dengan dikeluarkannya surat Gubernur Jawa Timur tertanggal $04 \mathrm{Mei}$ 2011 No.050/2004/202.2/2011. Hal tersebut kemudian ditindaklanjuti oleh Bupati Sumenep dengan diterbitkannya Keputusan Bupati Sumenep No. 188/38/KEP/435.013/2011 tentang Lokasi Program Pengembangan Kawasan Agropolitan. Program Pengembangan Kawasan Agropolitan ini berlokasi di Kecamatan Rubaru dengan komoditi unggulan bawang merah sebagaimana tercantum dalam Peraturan Daerah Kabupaten Sumenep Nomor 12 Tahun 2013 Tentang Rencana Tata Ruang Wilayah Kabupaten Sumenep Tahun 2013 - 2033. Untuk menunjukkan komitmen dan keseriusan pemerintah Kabupaten Sumenep, maka telah disusun Masterplan Pengembangan Kawasan Agropolitan pada tahun 2014. Dengan ditetapkannya kawasan Agropolitan Rubaru, serta telah disusunnya Masterplan Pengembangan kawasan Agropolitan maka pemerintah Kabupaten Sumenep membentuk panitia pelaksana kegiatan penyusunan perencanaan pengembangan kawasan agropolitan tahun anggaran 2017 dengan diterbitkannya Keputusan Bupati Sumenep Nomor: 188/122/KEP/435.012/2017. Berdasarkan hasil wawancara dengan Kepala Bappeda Kabupaten Sumenep dan Kepala Dinas Pertanian Kabupaten Sumenep bahwa sejumlah peraturan dan kebijakan tersebut dijadikan pegangan dalam upaya pengembangan sumber daya ekonomi lokal di Kabupaten Sumenep melalui program pengembangan kawasan agropolitan. Berdasarkan pada temuan-temuan penelitian tersebut, maka faktor adanya aturan dan kebijakan pemerintah daerah Kabupaten Sumenep, maka faktor ini diberi bobot 5 (sangat kuat) sebagai faktor pendorong karena aturan dan kebijakan tersebut merupakan landasan/pedoman bagi pelaksanaan pengembangan sumber daya ekonomi lokal. Tanpa adanya aturan dan kebijakan pemerintah yang menjadi landasan / pedoman maka pengembangan sumber daya ekonomi lokal di Kabupaten Sumenep tidak mungkin terlaksana dengan baik.

\section{Ketersediaan sumber daya manusia.}

Dinas Pertanian Tanaman Pangan, hortikultura dan Perkebunan Kabupaten Sumenep didukung dengan sumber daya manusia yang cukup memadai yaitu 126 personil, dengan rincian yaitu pejabat struktural berjumlah 48 orang, jabatan fungsional diisi oleh 59 personil ( 13 org pengamat hama dan penyakit tanaman (PHP) dan 46 orang Petugas Penyuluh Lapangan (PPL)), dan 32 staf. Namun demikian, mengingat luasnya wilayah pertanian dan potensi pertanian yang dimiliki Kabupaten Sumenep maka masih dibantu oleh 88 orang Tenaga Harian Lepas Tenaga Bantu Penyuluh Pertanian (THLTBPP). Ketersediaan sumberdaya manusia aparatur yang memadai akan mendukung upaya pengembangan sumber daya ekonomi lokal di Kabupaten Sumenep. 
Faktor ini diberi bobot 4 (kuat) sebagai faktor pendorong karena ketersediaan sumber daya manusia aparatur Dispertahortbun sebanyak 126 orang dan dibantu dengan 88 orang THLTBPP secara kuantitas dinilai cukup untuk melaksanakan tugas pokok dan fungsinya di Dispertahortbun Kabupaten Sumenep. Faktor ini lebih kuat dibandingkan faktor sarana dan prasarana karena faktor sumber daya manusia aparatur memegang peranan penting sebagai pelaksana program pengembangan sumberdaya ekonomi lokal di Kabupaten Sumenep. Sumber daya manusia merupakan satu-satunya sumber daya yang memiliki akal, perasaan, kemampuan, keterampilan, pengetahuan, dorongan untuk berkarya. Semua potensi yang dimiliki sumber daya manusia tersebut sangat berpengaruh terhadap pencapaian tujuan organisasi. Betapa pun majunya teknologi, berkembangnya informasi, tersedianya dana, namun jika tanpa ketersediaan sumber daya manusia maka akan sulit bagi organisasi untuk mencapai tujuannya.

\section{Komoditi Unggulan}

Pengembangan sumber daya ekonomi lokal di Kabupaten Sumenep dilaksanakan melalui program pengembangan kawasan agropolitan dengan komoditi unggulan yang dikembangkan yaitu bawang merah. Hal ini didasarkan pada keputusan menteri pertanian nomor: 2525/Kpts/SR.120/5/2011 tentang Pelepasan Bawang Merah Rubaru Sebagai Varietas Unggul. Bawang merah sumenep ini memiliki keunggulan yang potensial untuk dikembangkan secara serius. Disamping itu juga menurut Azmi dkk (2011: 206-213) potensi jumlah umbi varietas Sumenep cukup banyak, dapat mencapai 12-14 umbi. Varietas Sumenep juga lebih stabil terhadap amplitudo suhu. Bawang merah varietas Sumenep secara genetik memiliki aroma yang lebih tajam sehingga sangat cocok dan potensial untuk diolah menjadi bawang goreng. Menyikapi sejumlah keunggulan yang dimiliki oleh varietas bawang merah Sumenep maka Pemerintah Daerah Kabupaten Sumenep mengambil kebijakan untuk mengembangkan agropolitan bawang merah ini dari hulu ke hilir. Oleh karena itu maka faktor ini diberi bobot 4 (kuat) sebagai faktor pendorong.

\section{Ketersediaan Anggaran.}

Dukungan anggaran yang memadai merupakan faktor penting dalam keberhasilan pencapaian suatu program atau kegiatan. Begitu juga hal nya dalam pengembangan sumber daya ekonomi lokal di Kabupaten Sumenep juga harus didukung dengan anggaran dana yang memadai. Berdasarkan data yang tertuang dalam laporan Kinerja Instansi Pemerintah (LKjIP) tahun 2018 Anggaran Pendapatan TA. 2018 Rp. 207.018.880. Adapun anggaran Belanja Dinas Pertanian Tanaman Pangan Hortikultura dan Perkebunan Kabupaten TA. 2018 sebelum Perubahan sebesar Rp. 22.111.830.980,-setelah Perubahan menjadi Rp. 20.866.112.071. Faktor ini diberi bobot 4 (kuat) karena anggaran merupakan faktor penting dalam pelaksanaan sebuah program/kegiatan pengembangan sumber daya ekonomi lokal. Anggaran merupakan alat bantu manajemen dalam melaksanakan fungsi perencanaan dan pengendalian terhadap sebuah kegiatan. Anggaran juga merupakan alat bantu organisasi dalam mencapai tujuan yang telah ditetapkan. Anggaran merupakan rencana keuangan periodik yang disusun berdasarkan programprogram kegiatan yang telah disahkan organisasi. Anggaran berperan sebagai motor penggerak terlaksananya sebuah kegiatan. Menurut Mahsun (2012:49) dalam konteks anggaran organisasi sektor publik, anggaran mencakup biaya-biaya atas rencana program dan kegiatan yang akan dilaksanakan serta besaran dan cara memperoleh dana untuk mendanai program dan kegiatan tersebut. Anggaran juga merupakan alat ekonomi terpenting yang dimiliki oleh pemerintah untuk 
mengarahkan perkembangan sosial dan ekonomi, menjamin kesinambungan, dan meningkatkan kualitas hidup masyarakat. Dengan kata lain, anggaran merupakan alat utama kebijakan fiskal pemerintah. Anggaran sektor publik memiliki beberapa fungsi utama. Menurut Mahsun (2012:50) fungsi utama anggaran sektor publik yaitu: 1) sebagai alat perencanaan; 2) alat pengendalian; 3) alat kebijakan fiskal; 4) alat koordinasi; 5) alat penilaian kinerja; 6) alat motivasi; 7) alat politik; 8) alat menciptakan ruang publik. Mengingat pentingnya ketersediaan anggaran, oleh karena itu faktor ini diberi bobot 4 (kuat) sebagai faktor pendukung keberhasilan pengembangan sumber daya ekonomi lokal di Kabupaten Sumenep.

\section{Kepemimpinan}

Dalam upaya pengembangan sumber daya ekonomi lokal yang ditujukan untuk meningkatkan daya saing dan kesejahteraan masyarakat lokal, maka kepemimpinan memiliki peranan penting. Kepemimpinan yang dibutuhkan disini adalah kepemimpinan fasilitatif yang mampu membantu individu maupun kelompok membangun kapasitas mereka dalam pengembangan ekonomi lokal. Kepemimpinan fasilitatif merupakan kepemimpinan yang mampu meramu perannya sebagai pemimpin visioner dan pengatur dengan pemimpin yang mendengarkan dan memberdayakan. Sebagai pemimpin yang fasilitatif, maka dia akan selalu melibatkan pengikutnya dalam penyusunan visi misi secara maksimal dan membangun tim kerja yang kohesif. Kepemimpinan fasilitatif ini dimiliki oleh Bupati Sumenep ditunjukkan dengan komitmennya mendukung pengembangan sumber daya ekonomi lokal dengan diterbitkannya surat keputusan Bupati SumenepNo.188/138/KEP/435.013/2011

tentang lokasi pengembangan kawasan agropolitan. Masterplan pengembangan kawasan agropolitan juga telah disusun pada tahun 2014. Bupati Sumenep juga telah membentuk panitia pelaksana kegiatan penyusunan perencanaan pengembangan kawasan agropolitan pada tahun 2017. Pada tahun 2018 juga telah dibentuk panitia pelaksana kegiatan koordinasi perencanaan pembangunan kawasan agropolitan dengan SK Bupati Sumenep Nomor 188/145/KEP/435.012/2018. Susunan panitia kerja ini terdiri dari beberapa organisasi perangkat daerah antara lain Badan Perencanaan Pembangunan Kabupaten Sumenep, Dinas Pertanian Tanaman Pangan, Hortikultura dan Perkebunan Kabupaten Sumenep, Dinas Pekerjaan Umum Bina Marga, dan Dinas Pekerjaan Umum Sumber Daya Air. Panitia tersebut dibentuk sebagai upaya kolaborasi dari semua stakeholder yang terlibat dalam pengembangan agropolitan, juga untuk memudahkan koordinasi. Menurut Bjorna and Mikalsen (2015: 953) kepemimpinan fasilitatif telah lama menjadi slogan dalam studi tentang kepemimpinan walikota. Kepemimpinan fasilitatif menekankan kerja sama, pembangunan konsensus, dan pemberdayaan orang lain, model fasilitatif dikatakan khas dari sistem manajer dewan pemerintah daerah. Menurut Bussu and Bartels (2014: 2256) Kepemimpinan fasilitatif dapat memainkan peran penting dalam memungkinkan kolaborasi di antara para pemangku kepentingan lokal terlepas dari berbagai kepentingan yang beragam dan seringkali bertentangan.

Adapun faktor penghambat pengembangan sumber daya ekonomi lokal di Kabupaten Sumenep meliputi:

\section{Koordinasi dan Kolaborasi Stakeholder yang Terlibat}

Koordinasi dan kolaborasi stakeholder yang terlibat masih rendah dalam pengembangan sumber daya ekonomi lokal di Kabupaten Sumenep. Padahal, kolaborasi seluruh stakeholder akan memberikan hasil yang lebih baik dari pada dikerjakan sendirisendiri. Kolaborasi harusnya menjadi penting karena didalamnya terdapat kerjasama,komitmen dan koordinasi semua pihak yang terlibat 
membentuk sistem yang saling mempengaruhi untuk mencapai tujuan bersama menuju perubahan yang lebih baik (Najiati et al, 2015:220). Hubungan antara stakeholder yang terlibat saat ini masih berada pada tataran kerjasama dan koordinasi, dan masih berproses menuju kolaborasi. Idealnya, kolaborasi antara stakeholder yang terlibat diharapkan mampu mensukseskan program pengembangan sumber daya ekonomi lokal di Kabupaten Sumenep. Namun, permasalahan di lapangan seringkali dijumpai kurangnya keterlibatan dari stakeholder terkait ( Rahmawati et al, 2014: 363). Oleh karena itu maka faktor koordinasi dan kolaborasi stakeholder yang masih rendah di beri bobot 4 (kuat) sebagai faktor penahan.

\section{Komitmen Stakeholder yang Terlibat}

Pengembangan ekonomi lokal pada dasarnya merupakan usaha mengoptimalkan sumber daya lokal yang ada dengan melibatkan unsur pemerintah, pelaku usaha, masyarakat, kelembagaan dan masyarakat luar untuk mengembangkan perekonomian yang berkelanjutan. Upaya melibatkan stakeholder secara substansional pada kemitraan atau kolaborasi yang strategis yang tentunya tetap didominasi oleh masyarakat lokal tampaknya belum terwujud. Hasil penelitian menunjukkan bahwa kolaborasi lintas instansi belum berjalan baik karena konflik kepentingan, belum adanya tujuan bersama dan pola pengembangan ekonomi lokal yang belum tersistem. Sehingga masing-masing OPD cenderung memiliki prioritas sendiri, bekerja sendiri-sendiri mengejar target masing-masing OPD. Akibatnya masing-masing OPD cenderung menyusun program kegiatan sesuai dengan target masing-masing bukan karena tujuan bersama untuk keberhasilan pengembangan sumber daya ekonomi lokal. Hal ini sesuai dengan pendapat Najiati et al (2015) bahwa komitmen SKPD untuk berkontribusi dalam bentuk kegiatan kolaborasi pengembangan ekonomi lokal umumnya tinggi, namun komitmen untuk berkolaborasi dan bersinergi kurang, akibatnya banyak kegiatan dilakukan tetapi tidak saling berkaitan secara terencana. Kurangnya komitmen SKPD untuk bersinergi disebabkan karena faktor kendala readiness yaitu ketidaksiapan yang menyebabkan SKPD tidak tahu harus bagaimana membangun sinergisme. Disisi lain, kurangnya komitmen juga disebabkan oleh adanya konflik kepentingan dan kurangnya motivasi untuk bersinergi. Oleh karena itu, kurangnya komitmen stakeholder yang terlibat dikelompokkan menjadi faktor penghambat keberhasilan pengembangan sumber daya ekonomi lokal diberi bobot 4 (kuat).

\section{Ketersediaan Sarana Prasarana Pendukung}

Pengembangan sumber daya ekonomi lokal melalui program pengembangan kawasan agropolitan direncanakan akan dilaksanakan dari hulu ke hilir. Untuk itu perlu didukung dengan ketersediaan sarana prasarana pendukung mulai dari pemenuhan sarana produksi pertanian, perkembangan industri pembibitan, serta pengembangan industri olahan pertanian. Pemenuhan sarana prasarana produksi di lokasi pengembangan saat ini masih minim, tradisional dan diperuntukkan bagi konsumsi sendiri dan itu pun belum merata ke seluruh desa. Pemenuhan kebutuhan benih juga minim karena hanya memiliki dua penangkar saja. Begitupun dengan sistem irigasi yang ada saat ini masih menggunakan sistem irigasi konvensional. Ketersediaan sarana prasarana pendukung yang masih minim menyebabkan produktifitas bawang merah sebagai komoditi unggulan juga masih rendah jika dibandingkan dengan kabupaten lain di Jawa Timur, walaupun bawang merah sumenep memiliki sejumlah keunggulan dibandingkan varietas lain. Berkenaan dengan pengembangan industri olahan juga masih membutuhkan dukungan sarana prasarana baik alat pengolahan, tirisan, pengemasan sampai pemasaran produk. Daya dukung sarana prasarana dikategorikan sebagai faktor penghambat dalam pengembangan sumber daya ekonomi lokal sebab belum dapat 
terpenuhi sesuai kebutuhan yang seharusnya. Namun demikian pemerintah daerah kabupaten sumenep memiliki kepedulian dengan keterbatasan APBD nya tetap melakukan pengadaan sarana-prasarana yang dibutuhkan setiap tahun, meskipun belum sepenuhnya terpenuhi. Oleh karena itu daya dukung sarana prasarana diberi bobot 3 (cukup kuat).

\section{Kualitas SDM Petani Masih Rendah}

Kualitas sumber daya manusia petani di lokasi pengembangan agropolitan masih rendah. Peningkatan kapasitas petani, pengetahuan, keterampilan dan penguasaan teknologi pertanian perlu ditingkatkan secara terus menerus dan berkesinambungan. Upaya ini tidak hanya mengandalkan pendampingan dari petugas penyuluh lapangan namun juga harus diiringi dengan pelatihan, bimbingan teknis dan pendekatan dengan perspektif kearifan lokal. Tidak mudah merubah paradigma dan mindset petani yang merupakan masyarakat desa, pada umumnya berpendidikan rendah. Untuk itu perlu dilakukan pendekatan persuasif yang sesuai dengan kearifan lokal masyarakat setempat. Kualitas SDM petani yang masih rendah diberi bobot 4 ( kuat) sebagai faktor penghambat pengembangan sumber daya ekonomi lokal.

\section{Partisipasi Masyarakat}

Partisipasi masyarakat dalam proses pembangunan merupakan hal yang memiliki arti penting bagi keberhasilan pembangunan itu sendiri. Hasil wawancara dengan informan menunjukkan bahwa partisipasi masyarakat kurang. Hal ini disebabkan oleh faktor internal dan eksternal dari masyarakat. Faktor eksternal yang mempengaruhi tingkat partisipasi adalah adanya indikasi sebagian masyarakat tidak terjangkau, tidak tahu dan tidak dilibatkan dalam proses pengembangan ekonomi lokal sehingga mereka tidak memiliki kesempatan untuk berpartisipasi. Adapun faktor internal yang mempengaruhi tingkat partisipasi masyarakat rendah sebagaimana hasil wawancara adalah motivasi yang rendah dari sebagian masyarakat untuk berpartisipasi karena mereka menganggap ada kepentingan lain yang lebih menguntungkan, atau mereka tidak tahu bagaimana cara berpartisipasi. Padahal, tingkat partisipasi masyarakat turut menentukan keberhasilan pengembangan ekonomi lokal. Harusnya pemerintah mampu melibatkan masyarakat dalam setiap prosesnya walaupun hanya sebatas dialog untuk mengakomodir aspirasi dan keinginan masyarakat. Menurut Muluk (2004) tangga kedua partisipasi masyarakat terdiri dari tiga tingkatan yang melibatkan dialog dengan publik. Masyarakat dalam derajat yang berbeda, memiliki hak untuk didengar meski tidak terlibat langsung dalam pengambilan keputusan. Dalam tangga ini ada beragam situasi mulai dari komunikasi satu arah dari pemerintah kepada masyarakat yang disebut tingkatan information (seperti pengumuman,poster, laporan tahunan), komunikasi dua arah yang disebut tingkatan consultation (dengar pemdapat, pertemuan warga), sampai pelibatan yang disebut placation (melibatkan masyarakat menjadi anggota komite namun hak memutuskan tetap berada di tangan pemegang kekuasaan). Tingkat partisipasi masyarakat yang masih rendah dalam pengembangan ekonomi lokal maka diberi bobot 4 (kuat) sebagai faktor penghambat.

Berdasarkan identifikasi serta skoring terhadap faktor pendorong dan faktor penghambat terhadap pengembangan sumber daya ekonomi lokal di Kabupaten Sumenep maka dapat disusun strategi untuk memperkuat kekuatan pendorong atau memperlemah kekuatan penghambat yaitu sebagai berikut:

1) Pemerintah daerah perlu menyusun satuan kerja pengembangan sumber daya ekonomi lokal yang terdiri dari lintas OPD yang terlibat untuk berkolaborasi dan bersinergi sehingga tujuan peningkatan daya saing dan kesejahteraan masyarakat dapat terwujud optimal. 
2) Meningkatkan koordinasi dan kolaborasi stakeholder yang terlibat dengan melepaskan ego sektoral serta menyusun rencana kerja yang terintegrasi.

3) Meningkatkan kualitas sumber daya manusia aparatur dan sumber daya manusia petani secara komprehensif dan berkesinambungan dengan manajemen diklat dan penggunaan teknologi tepat guna.

4) Mengoptimalkan penyelenggaraan penyuluhan pertanian yang lebih efektif melalui organisasi Gabungan Kelompok Tani (Gapoktan) tingkat desa dan Kecamatan.

5) Meningkatkan partisipasi masyarakat dengan melakukan pendekatan berbasis kearifan lokal dan melaksanakan pemberdayaan masyarakat.

6) Pemberdayaan masyarakat petani bawang merah Rubaru melalui penerapan teknologi tepat guna serta pengembangan aktifitas ekonomi masyarakat berbasis komoditas lokal.

7) Penguatan Kelembagaan Petani serta menumbuhkan kembangkan kelompok usaha bersama Pengolahan Hasil/ Pengolahan pangan melalui Kelompok Wanita Tani.

8) Merintis usaha pemasaran bersama produk pangan lokal pada lokasi kunjungan wisata serta upaya promosi produk unggulan melalui pasar lelang, pameran serta pemanfaatan media elektronik (web-site disperta).

9) Menyusun perencanaan penggunaan anggaran pengembangan sumber daya ekonomi lokal dengan optimal.

10) Mewujudkan sinkronisasi pencapaian target dengan alokasi anggaran yang tersedia sehingga sisi kualitas dari kegiatan yang dilaksanakan dapat tercapai bukan sekedar tuntutan penyerapan anggaran semata.

\section{PENUTUP}

Upaya pengembangan sumber daya ekonomi lokal memiliki beberapa faktor pendorong dan faktor penahan yang dianalisa menggunakan force field analisis. Faktor pendorong yaitu adanya aturan/kebijakan, komoditi unggulan, ketersediaan sumber daya manusia, anggaran dana dan kepemimpinan. Faktor penahan yaitu kurangnya koordinasi dan kolaborasi stakeholder yang terlibat, rendahnya komitmen dari para stakeholder, rendahnya partisipasi masyarakat, rendahnya kualitas sumber daya manusia petani, ketersediaan sarana prasarana yang belum optimal. Dengan menggunakan force fields analysis, maka dapat ditentukan strategi untuk semakin menguatkan faktor pendorong dan melemahkan faktor menghambat. Berdasarkan hasil analisis dapat disimpulkan bahwa dapat tercipta kondisi yang memungkinkan untuk mencapai tujuan pengembangan sumber daya ekonomi lokal yaitu peningkatan daya saing dan kesejahteraan masyarakat.

\section{DAFTAR PUSTAKA}

Badan Penelitian dan Pengembangan Pertanian. (2019). Info Aktual. Diakses dari https:/ / www.litbang.pertanian.go.id/info -aktual/3521/

Blakely, E. J. (1994). Planning Local Economic Development. Theory and Practice.

Canzanelli, G. (2001). Overview and learned lessons on Local Economic Development, Human Development, and Decent Work. Economic Geography.

Cordell, A., Thompson, I., Cordell, A., \& Thompson, I. (2019). Force Field Analysis. In The Procurement Models Handbook.

https://doi.org/10.4324/978135123950 9-51

Daft, R. L., \& Marcic, D. (2016). Understanding management. (Sixth Edit). Nelson Education, Ltd.

Najiyati, S; Simanjuntak, RA; Nurwati, N. (2015). Synergism of Local Economic Development Components for Increase in Social Welfare at Telang and Batu Betumpang Rural Areas. Kajian Ekonomi Dan Keuangan, 19 No.3, 218-245. 
Pike, A., Marlow, D., McCarthy, A., O'Brien, P., \& Tomaney, J. (2015). Local institutions and local economic development: The Local Enterprise Partnerships in England, 2010-. Cambridge Journal of Regions, Economy and Society. https://doi.org/10.1093/cjres/rsu030

Rahma, H. (2012). Acuan Penerapan Pengembangan Ekonomi Lokal untuk Kota dan Kabupaten. Direktorat lenderal Cipta Karya. Kementerian Pekerjaan Umum.

http://ciptakarya.pu.go.id/usdrp/site s/default/files/pembelajaran/Buku PEL 2012 Final.pdf

Rokhim, R., Wahyuni, S., Wulandari, P., \& Ayu, F. (2017). Analyzing key success factors of local economic development in several remote areas in Indonesia. Journal of Enterprising Communities. https://doi.org/10.1108/JEC-09-20150049
Swanson, D. J., \& Creed, A. S. (2014). Sharpening the Focus of Force Field Analysis. Journal of Change Management. https://doi.org/10.1080/14697017.201 3.788052

Swinburn, Gwen; Goga, Soraya; Murphy, F. (2006). Local Economic Development: A Primer Developing and Implementing Local Economic Development Strategies and Action Plans (Hungarian). http:/ / documents.worldbank.org/cur ated/en/211891468140975725/Localeconomic-development-a-primerdeveloping-and-implementing-localeconomic-development-strategies-andaction-plans

Wiranta, D. N. (2015). Penguatan Peran Pemerintah Daerah dalam Mendorong Pertumbuhan Ekonomi Lokal: Peluang dan Tantangan Masyarakat Ekonomi ASEAN (MEA) 2015. Lingkar Widyaiswara. 